\title{
SEJARAH KOTA SUBULUSSALAM
}

\author{
Oleh : \\ Pulung Sumantri \\ Eva Susanti Bako
}

\begin{abstract}
ABSTRAK
Penelitian ini bertujuan untuk mengetahui sejarah Kota Subulussalam, untuk mengetahui kondisi dan perkembangan Kota Subulussalam sebelum dan setelah menjadi ibukota. Penelitian ini dilaksanakan di Kota Subulussalam. Untuk memperoleh data yang diperlukan dalam penyusunan dari skripsi ini digunakan metode penelitian lapangan (field research) dengan pendekatan deskriptif kualitatif, dimana data diperoleh dari lapangan yang berhubungan dengan permasalahan penelitian. Data juga diperoleh dari hasil wawancara dengan para tokoh yang mengetahui tentang sejarah dan perkembangan dari Kota Subulussalam, selain itu data juga diperoleh dari hasil observasi.Dari hasil penelitian, peneliti dapat mengetahui tentang sejarah Kota Subulussalam. Pertama, pada masa masih menjadi kecamatan, ibukota Kecamatan Simpang Kiri adalah Runding. Letak daerah Runding yang berada ditepi sungai soraya sering terjadi banjir Dalam perkembangannya, selain dari perubahan nama juga terjadi perubahan jumlah penduduk, luas wilayah, transportasi dan lainnya. Kedua, hasil temuan peneliti dalam perkembangan Subulussalam yaitu terjadinya perubahan bangunan, mata pencaharian, transportasi dan jumlah penduduk.
\end{abstract}

Kata Kunci: Sejarah, Subulussalam

\section{PENDAHULUAN}

Kota merupakan pusat pemukiman dan kegiatan masyarakat, memiliki batasan wilayah administrasi yang sifatnya non agraris, orang-orang didalamnya bersifat individualis. Kota erat kaitannya dengan desa dimana kota merupakan hasil dari perkembangan desa. Seperti yang kita tahu bahwa pada awalnya kota-kota merupakan desa dan tempat bermukim para petani, peternak, nelayan dan lain-lainnya. Mereka saling berhubungan, berkomunikasi dan berinteraksi.Tahap terbentuknya kota mengalami proses yang sangat panjang, tidak terlepas dari berbagai proses kultural dari masyarakat sehingga melahirkan sebuah kota.

Hal ini dapat di baca dalam Mirsa (2012:13) mengatakan bahwa kota merupakan suatu daerah yang memiliki wilayah batas administrasi dan bentang lahan 
luas, penduduk relatif banyak, adanya heterogenitas penduduk, sektor agraris sedikit atau bahkan tidak ada dan adanya suatu sistem pemerintahan. Desa memberikan kemungkinan kepada masyarakat untuk melangsungkan kehidupan karena luasnya lahan yang dapat diolah, masyarakat desa kebanyakan hidup sebagai petani. Selain bercocok tanam, beternak, menjala ikan dan lainnya, desa juga digunakan sebagai tempat menjalin pergaulan maupun ikatan-ikatan kekerabatan dan persaudaraan yang baik. Corak kehidupan di desa di landaskan pada ikatan kekerabatan yang kuat. Banyak kegitan yang dilakukan dengan cara gotong royong sehingga jauh dari sifat individualis.

Tidak seperti di kota, desa masyarakat masih bebas untuk menanam berbagai jenis tanaman seperti sayur-sayuran, padi, jagung, ubi dan lain sebagainya. Segala hasil yang di olah oleh masyarakat desa biasanya di salurkan ke tempat yang mampu menampung hasil desa yaitu kota. Kota juga berjasa karena memproduksi barangbarang yang dibutuhkan oleh penduduk desa di sekitarnya, sebaliknya kota juga mengkonsumsi bahan yang dihasilkan pedesaan. Biasanya perdagangan antar desa kota banyak yang merupakan hasil dari desa-desa terdekat dengan kota, yang paling utama yaitu hasil pertanian yang disalurkan ke kota dengan lancar sehingga warga kota dapat mengkonsumsi sayur-mayur dan buah-buahan yang masih segar yang biasanya di dapat masyarakat kota melalui pasar. Faktor yang menyebabkan lahirnya permukiman berupa kota diakibatkan karena telah cukupnya bahan pangan yang dihasilkan oleh pedesaan. Dengan sendirinya ada orang-orang yang terbebaskan dari pekerjaan mengolah tanah. Masyarakat mulai hidup dari kegiatan non-agraris, misalnya dagang, transportasi. Salah satu faktor pemicu lainnya adalah perkembangan teknologi yang serba cepat. Tidak hanya dari teknologi, dikota jugalah berkembang kebudayaan umat manusia. Hal ini bisa kita lihat pada tingginya keterampilan teknis, berkembangnya gagasan manusia, majunya berbagai bidang kesenian dan munculnya segala penemuanpenemuan baru.

Kota Subulussalam adalah salah satu daerah pemerintahan kota yang berada di wilayah barat Provinsi Aceh. Kota Subulussalam berkembang cukup pesat dalam 
segala bidang dan merupakan pusat dari kegiatan masyarakat yang saat ini terletak di Kecamatan Simpang Kiri. Karena pada hakikatnya ibukota merupakan suatu sistem jaringan kehidupan manusia yang ditandai dengan pusat permukiman dan kegiatan penduduk, serta sebagai pusat aktivitas manusia yang meliputi pusat pemerintahan, pusat perekonomian dan lainnya.

Sawit merupakan hasil perkebunan yang paling menonjol dari Kota Subulussalam dan merupakan salah satu ikon atau ciri khas dari kota tersebut. Sehingga para pedatang yang baru berkunjung dapat mengetahui bahwa potensi utama kota ini adalah sawit. Satu hal yang tidak dapat disangkal lagi,yaitu adanya kenyataan bahwa masing-masing kota mempunyai potensi dan fungsi-fungsi yang berbeda-beda. Hal ini lebih banyak bersangkut paut dengan latar belakang historikal, cultural, fisikal, kemasyarakatan, ekonomi dan lainnya yang saling berkaitan dan bersama-sama memberi warna terhadap suatu kota tertentu. (Yunus .2005:6)

Kota Subulussalam merupakan kota yang strategis. Secara historik, konon pusat kota Subulussalam dulunya berada di Rundeng. Rundeng merupakan tempat yang strategis karena di lintasi oleh sungai Soraya. Pada saat itu jalur transportasi yang paling popular adalah melalui jalur air. Sungai Soraya ramai di kunjungi karena selain melintasi Rundeng, juga melintasi gelombang, kota Cane atau bahkan melewati Aceh Tenggara. Seiring dengan perkembangan jaman ibukota mengalami beberapa kali pergantian wilayah, dimulai dari Rundeng kemudian pindah ke Bustaniyah dan Simpang Empat yang kemudian diganti nama menjadi Bandar Baru. Hingga pada tanggal 14 September oleh Gubernur aceh yang pada saat itu di jabat oleh Prof.Ali Hasyimi mengganti nama Simpang Empat menjadi Subulussalam atau “jalan menuju kedamaian".

Seiring dengan perkembangan zaman, jalur transportasi Kota Subulussalam berubah melalui jalur darat. Majunya transportasi merupakan suatu faktor utama yang mengakibatkan berkembangnya suatu kota sehingga memberikan pengaruh yang sangat besar terhadap pertumbuhan kota. Secara geografis Kota Subulussalam pada zaman dulu banyak kita jumpai sungai-sungai besar seperti sungai Lae Soraya yang 
merupakan sungai besar yang melintasi Kota Subulussalam di batas barat kota, sungai Lae Kombih yang membentang dari timur ke barat kota,sungai Lae Batu-Batu mengalir melintasi Kecamatan Sultan Daulat dan Kecamatan Rundeng, sungai Lae Belegen yang mengalir dari Kecamatan Simpang Kiri menuju Kecamatan Rundeng dan bermuara di sungai Lae Soraya dan masih banyak sungai yang lainnya. Hal ini memberikan corak bahwa dahulunya Kota Subulussalam menggunakan jalur transportasi air yaitu melalui jalur sungai dengan mengunakan sampan atau yang di sebut dalam bahasa Boang yaitu Bongki. Perbaikan dan pembangunan jalan dilakukan mulai dari awal pemekaran sampai sekarang ini.

Pada awal pemekaran kota Subulussalam tahun 2007 panjang jalan kota subulussalam sekitar 269,26 jalan yang didata peningkatan pembangunan sudah mulai di tingkatkan. Sudah banyak kendaraan yang diguanakan masyarakat dalam berlalulalang melintasi Kota Subulussalam, sarana transportasi mulai di tingkatkan baik transportasi antar kota, transportasi antar kota ke desa maupun angkutan antar provinsi.

Menno dan Alwi (2012:18) menjelaskan bahwa jika dilihat dari segi fisik kotakota merupakan suatu pemukiman yang menpunyai bangunan-bangunan yang jaraknya antara satu dengan yang lainnya relatif rapat serta memiliki sarana-sarana dan prasarana - prasarana serta fasilitas-fasilitas yang memadai untuk memenuhi kebutuhan sehari-hari warganya. Sarana, prasarana dan fasilitas di perkotaan antara lain jalan, air minum, penerangan, sarana ibadah, pertokoan, pasar, lembaga dan bangunan pemerintahan, rekreasi, olahraga, peribadatan, listrik, lembaga-lembaga yang mengatur kehidupan bersama warganya, pendidikan dan lain-lain.

Kota Subulussalam memiliki luas daerah yang sangat besar mencapai 139.100 hektar, pada pertengahan tahun 2008 jumlah penduduknya berkisar 68.729 jiwa dengan jumlah penduduk laki-laki 33.883 jiwa dan perempuan 34.846 jiwa, bahwa terdapat lebih banyak jumlah penduduk perempuan di bandingkan dengan laki-laki. Laju pertumbuhan kota Subulussalam cukup tinggi yaitu pada tahun 2014 jumlah penduduk mencapai 73.708 jiwa. Mempunyai penduduk dari berbagai latar belakang etnis 
diantaranya Etnis Singkil (boang), etnis Batak (Pak-pak), etnis Aceh, Etnis Alas,Minang dan Jawa menjadikan kota ini sebagai kota yang multi etnis.

Dalam komunikasi sehari-hari penduduk Kota Subulussalam menggunakan bahasa daerah yaitu Bahasa Boang dan Bahasa Pak-pak. Mempunyai lingkungan sosial tersendiri, segala tingkah laku dan pola hidup yang dilalui memiliki ciri sendiri karena letak geografis juga mempengaruhi segala tingkah laku pada masyarakat. Seperti yang kita tahu bahwa banyak kota yang ada sekarang mempunyai fungsi sebagai pusat perdagangan tetapi dulunya kota tersebut berfungsi sebagai pusat keagamaan atau pusat pemerintahan. Perubahan fungsi tersebut sejalan dengan makin majunya fasilitasfasilitas perkotaan yang ada dan kemajuan teknologi. Hal ini dapat kita lihat dari makin majunya teknik di bidang komunikasi dan transportasi. Pada masa sekarang inikebanyakan kota-kota yang ada mempunyai fungsi jamak (multi function city). Hal ini disebabkan karena manusia mempunyai kegiatan-kegiatan yang beraneka seperti kegiatan politik, kegiatan sosial, kegiatan ekonomi, kegiatan budaya yang pada umumnya berpusat pada umumnya berpusat di kota-kota tersebut (Yunus.2005:6).

Untuk lebih mengarahkan peneliti dalam melaksanakan penelitian dan lebih mempermudah merumuskan masalah penelitian yang lebih objektif, maka peneliti merumuskan penelitian yaitu: 1.Bagaimana sejarah berdirinya Kota Subulussalam, 2.Bagaimana Perkembangan Kota Subulussalam sebelum dan sesudah menjadi ibukota.adapun tujuan di lakukan penelitian ini adalah untuk mengetahui sejarah berdirinya Kota Subulussalam, untuk mengetahui Perkembangan Kota Subulussalam sebelum dan sesudah menjadi ibukota. Adapun metode yang digunakan dalam penelitian ini adalah penelitian lapangan (field research) dengan pendekatan deskriptif kualitatif, dimana sumber data yang diperoleh dari lapangan berhubungan dengan permasalahan penelitian. Membuat dan menemukan sumber primer dan sekunder melalui hasil wawancara, observasi dan penelitian. Untuk menganalisis data maka dilakukan beberapa tahapan yaitu dengan memilah dan memilih data primer dan sekunder untuk di analisis, menginterpretasi (menyusun hasil-hasil penelitian 
berdasarkan fakta) data berdasarkan data primer dan sekunder dan menyimpulkan data dan menuangkannya kedalam bab pembahasan.

\section{PEMBAHASAN}

\section{A. Sejarah Kota Subulussalam}

Kampung pertama sekali sebagai cikal bakal Kota Subulussalam adalah Runding. Berdasarkan letak geografi dari runding yang tepat berada di pinggiran sungai Soraya yang rentan akan bencana banjir dan juga karena runding pada saat itu di pindahkan oleh gubernur Ali Hasyim ke tempat yang lebih aman dari banjir ke Bustamiyah. Mata pencaharian masyarakat pada saat itu juga belum terfokus pada satu bidang. Masyarakat yang menggantungkan hidupnya dengan bertani harus mencari lahan pertanian yang jauh dari sekitar sungai soraya hal ini di karenakan banjir yang terjadi akibat luapan sungai Soraya yang kerap terjadi tiap tahun. Hama yang menyerang tanaman masyarakat juga banyak. Sehingga satu-satunya mata pencaharian masyarakat adalah sebagai nelayan tradisional.

Sebelum Simpang Empat pemerintahan pernah dipindahkan ke Bustamiyah, masyarakat Rundeng bermusyawarah memindahkan Ibukota Kecamatan Simpang kiri denagn jarak tempuh $6 \mathrm{Km}$ dari Pasar Rundeng, nama tempat tersebut adalah Bustaniyah ( Kilometer 6 ) yang lazim disebut Rundeng baru ( sekarang menjadi kampung harapan baru). Atas kesepakatan masyarakat tersebut, maka dibangunlah sebuah bangunan untuk di jadikan kantor Asisten Wedana Kecamatan Simpang Kiri, Masyarakat telah mengambil kapling lahan masing-masing untuk perumahan pada saat itu kondisi bangunan asisten wedana sangat sederhana sekali dinding rumah terbuat dari kayu dan atapnya terbuat dari tarum rumbia. Masyarakat yang mendiami daerah itu sangat sedikait bisa di hitung kepala orang tinggal disana . Tetapi pada saat melakukan kunjungan Camat ( bapak Raja Ulasi ) ke Aceh Selatan. Camat menghadap Bupati Aceh selatan untuk mengusulkan pemindahan Ibukota Kecamatan Simpang Kiri ke Bustaniyah (Km6) beserta staf, pada saat itu Bupati Aceh Selatan yang bernama 
Teuku Tjut Mamat sadang bertugas di luar daerah yakni banda aceh, maka yang menerima kedatangan camat adalah Patih TM Yunan.

Hasil dari pembicaraan antara camat dan Patih TM. Yunan tidak menemukan titik terang, karna Patih TM Yunan tidak menyetjui pemindahan ibukota kecamatan simpang kiri ke bustaniyah dengan alasan dan pertimbangan bahwa bustaniyah ( $\mathrm{Km}$ 6) belum ada penduduk yang mendiami desa tersebut. Tahun 1960-an di bawah pimpinan Gubernur Ali Hasyim disosialisasikan sebuah program pemerintah daerah yang dikenal dengan sebutan resettlement desa ( program pemerintah daerah Nangro Aceh Darusalam untuk memberikan tempat menetap yang baru bagi masyarakat desa yang tertinggal ). Gubernur Aceh tersebut menunjuk Kabupaten Singkil menjadi lokasi daerah kerja BKPMD ( Badan Koordinasi Pembangunan Masyarakat Desa) kabupaten singkil yang bernama Aripin Thaib menunjuk kecamatan simpang kiri menjadi daerah BKPMD, yang belokasi disimpang empat kemukiman kombih karna simpang empat bertetangga dengan kemukiman penanggalan dan kemukiman belegen , pada waktu simpang empat belum memuliki ststus, yang ada hanya kampong pegayo (sekarang bernama mekem), karna letak desa tersebut berada diempat persimpangan yaitu, rundeng, penanngalan, mekem, dan belegen oleh penduduk disebut desa simpang empat.

Pada awal perpindahan ke simpang empat, suasan juga sangat sulit, terbatasnya jumlah penduduk, kehidupan penduduk awal ( suku Pak-Pak ) yang kolot atau terbelakang membuat semuanya harus susun dari awal. Pertama kali datang ke simpang empat ibu Latifah dan bapak Raja Ulasi menumpang di rumah warga dengan kondisi yang seadanya. Masyarakat yang mendiami Simpang Empat awalnya kurang dari 30 kepala rumah tangga. Sehingga pembangunan Kantor asisten wedana dilakukan secara bergotong royong. Pembangunan asisten wedana dilakukan dan kembali lagi dengan dinding papan dan atap rumbia. Rumah masyarakat awalnya terbuat dari Rih (atap ilalang).

Awal tahun 1962, bupati simpang kiri T.Tjut Mamat bersama Dandim 0107 Aceh selatan melalui kunjungan dinas ke kecamtan simpang kiri mengadakan 
musyawarah untuk rencana pemindahan ibukota kecamatan simpang kiri ketempat lain, musyawarah tersebut dihadiri bupati singkil dan kepala jawatan, pada saat itu baru ada empat jawatan yakni, kantor urusan agama, juru penerangan, kantor kehutanan dan balai pengobatan serta kepala mukim binanga yang bernama alm. H. M. Layakhi. Para kepala kampung dalam kemukiman binanga dan toko-tokoh masyarakat. Hasil dari musyawarah tersebut memutuskan bahwa ibukota kecamatan simpang kiri dipindahkan ke simpang empat lokasi BKPMD waktu status kampung masih dipegayo. Berbekal hasil musyawarah, kantor camat di Bustaniyah (Km 6 ) dipindah kesimpang empat dalam keadaan darurat dengan atap dari rumbia, tiang dan dinding dari kayu berlantai tanah.

Tangal 13 September 1963, gubernur Aceh Prof.Ali Hasymi berkunjung ke kecamatan simpang kiri. Gubernur disambut secara adat dengan tepung sitawar dan dikalungi bunga yang dirangkai dengan kain oleh ibu $\mathrm{Hj}$ latifah. Ketika gubernur memberikan kata sambutannya yang di sambut dengan penuh semangat, lugas dan berwibawa, beliau dengan tegas menganti nama bandar baru menjadi Subulusalam yang memiliki arti jalan menuju keselamatan, kesejahteraan yang mana nama tersebut di ambil dari penggalan kata dari kitab suci Al-Quran. Disahkan dengan surat keputusan gubernur Nomor Istimewa/XI/1962 pada tangal 14 September 1962 sekaligus dilanjutkan dengan peletakan batu pertama pembangunan Masjid Jamik di ibu kota kecamatan simpang kiri.

Awalnya Subulussalam merupakan daerah dari Kabupaten Aceh Singkil yang merupakan salah satu kabupaten yang baru mekar dari Kabupaten Aceh Selatan pada tahun 1999. Kabupaten Aceh Singkil lahir lewat UU No 14 tahun 1999, sebagai pemekaran dari Kabupaten Aceh Selatan. Hanya berselang 8 tahun baru mekarlah kota Subulussalam. Kota ini dibentuk berdasarkan Undang-Undang Nomor 8 Tahun 2007, pada tanggal 2 Januari 2007. Hal ini dikarenakan banyaknya jumlah penduduk, luas wilayah yang memadai, pertanian atau perkebunan yang merupakan potensi utama penunjang kebutuhan masyarakat kota subulussalam sehingga memungkinkan Subulussalam menjadi sebuah kota. 
Kota ini berbatasan langsung dengan provinsi Sumatra Utara. Sebelah utara kota ini berbatasan dengan Kecamatan Lawe Alas, Kabupaten Aceh Tenggara dan Kabupaten Dairi, Sumatra Utara. Sebelah selatan Subulussalam berbatasan dengan Kecamatan Singkohor dan Suro Baru, Kabupaten Aceh Singkil. Sebelah Timur Subulussalam berbatasan dengan Kabupaten Dairi Dan Kabupaten Pak-Pak Barat, Sumatra Utara dan sebelah barat berbatasan dengan Kecamatan Trumon dan Trumon Timur, Kabupaten Aceh Selatan. Secara geografis, Kota Subulussalam terletak pada posisi $2^{\circ} 27^{\prime} 30^{\prime \prime}-3^{\circ} 00^{\prime} 00^{\prime \prime} \mathrm{LU}$ dan $97^{\circ} 45^{\prime} 00^{\prime}-98^{\circ} 10^{\prime} 00^{\prime}$ BT dengan luas wilayah $1.391 \mathrm{Km}^{2}$.

Kota ini merupakan daerah hasil pemekaran dari kabupaten Aceh Singkil yang baru 9 tahun, tepatnya tanggal 2 januari 2007. Kota Subulussalam terbentuk dengan keluarnya undang-undang Nomor 8 tahun 2007. Adapun pejabat walikota yang memimpin Kota Subulussalam yaitu walikota yang pertama yaitu Bapak Asmauddin, SE, beliau menjabat hingga Bulan Juni 2008. Kemudian pada tanggal 30 juni 2008 dilantik pejabat walikota yang baru yaitu Bapak Drs. H. Marthin Desky, MM. yang menjabat hingga bulan April 2009. Selanjutnya walikota Subulussalam saat ini adalah bapak Merah Sakti, SH. yang dilantik pada tanggal 5 April 2009.

\section{B. Perkembangan Kota Subulussalam}

Sebelum menjadi kota Subulussalam yang sekarang, subulussalam juga memiliki syarat minimal jumlah penduduk agar dapat menjadi sebuah kota. Sampai pada tahun 1970-an jumlah penduduk di Subulussalam masih sedikit. Pada tahun 1980an barulah terjadi transmigrasi, dengan demikian syarat jumlah penduduk yang diberikan telah terpenuhi dengan penduduk suku Jawa sebanyak 30\% sehingga mencukupi jumlah penduduk sebanyak 2.500 orang. Transmigrasi menciptakan persebaran tenaga kerja yang lebih merata di seluruh nusantara, yang ada gilirannya akan memperluas kesempatan berusaha, mengemban potensi daerah, mengurangi kesenjangan wilayah, membantu mengentaskan rakyat dari kemiskinan, serta akan mengukuhkan persatuan dan kesatuan. 
Adanya transmigrasi orang jawa ke Subulussalam juga menyusul adanya penduduk tranmigrasi lokal sebanyak $10 \%$ atau sekitar dalam artian agar masyarakat daerah diarahkan untuk menggali potensi daerah Subulussalam, untuk mempelajari budaya lain dan untuk mengarahkan masyarakat mengembangkan pertanian di daerah yang ditempati. Letak Kota Subulussalam sangat trategis tepat berada di Kecamatan Simpang Kiri. Bagian wilayah Kota Subulussalam memiliki dataran rendah yang jumlahnya mencapai 65,94 \% sehingga sangat cocok dijadikan sebagai lahan pertanian. Sebagian masyarakat berprofesi sebagai petani. Tanaman yang ditanam mencakup padi, jagung, semangka, coklat, sawit, karet, kelapa, cabai dan lain sebagainya. Sebanyak 34,06 \% lahannya merupakan daerah perbukitan.

Luas wilayah kecamatan yang terbesar di Kota Subulussalam adalah Kecamatan Sultan Daulat dengan luas 60.200 hektar atau 43,28 \% dari luas wilayah Kota Subulussalam. Kemudian di susul oleh Kecamatan Runding dengan luas 33.200 hektar atau 23,87 \% dari luas Kota Subulussalam. Selanjutnya Kecamatan Simpang Kiri seluas 21.300 hektar dan Kecamatan Longkib memiliki luas 15.100 hektar atau $10.86 \%$ dari total luas Kota Subulussalam.

Selain itu terdapat wilayah terkecil, yaitu Kecamatan Penanggalan yang hanya memiliki luas wilayah 9.300 hektar atau hanya $6.69 \%$ dari total luas wilayah Kota Subulussalam. Pada awalnya pusat pemerintahan Kota Subulussalam atau kantor walikota mempungsikan bangunan bekas kantor camat simpang kiri, tepatnya di kecamatan simpang kiri. Karena berbatasan dengan Sumatera Utara mengakibatkan terjadinya hubungan yang erat dengan Provinsi Sumatra Utara hal ini di sebabkan karena jarak tempuh ke Sumatra Utara lebih dekat di bandingkan dengan Provinsi Aceh. Untuk menuju Kota Subulussalam dari kota medan yaitu Ibukota Sumatra Utara yang merupakan kota terbesar nomor 3 di Indonesia itu dapat ditempuh selama 7 jam.

Berbeda jika melalui banda aceh yaitu ibukota Provinsi Aceh waktu yang dihabiskan adalah selama 16 jam. Inilah yang menjadi alasan dan faktor yang menyebabkan masyarakat Subulussalam lebih meyukai perjalanan ke Medan daripada ke Banda Aceh. Selain itu terdapat faktor lain yang menyangkut kebutuhan sandang, 
pangan dan papan yang dianggap jauh lebih murah di Medan daripada di banda aceh. Untuk menempuh perjalanan dari Kota Subulussalam ke medan tidak semulus seperti yang menempuh perjalanan dari Subulussalam ke aceh. Karena jalur yang dilalui ketika menuju kota medan ataupun daerah Sumatera Utara lainnya mengalami kendala karena kerusakan terutama daerah perbatasan Pak-Pak Bharat.

Daerah Subulussalam juga di lintasi oleh sebuah sungai besar yang bermuara ke Samudra Hindia yang bernama Lae Soraya. Di sekitar Lae Soraya inilah orang boang bermukin dan hidup secara turun temurun. Kota ini berada di sebuah lembah yang dikelilingi oleh perbukitan yang bernama bukit barisan. Bukit barisan tersebut memanjang dari utara hingga selatan pulau Sumatra dan merupakan salah satu lintasan merapi yang paling aktif di dunia.

Sepanjang perjalanan yang lalui dari Pak-Pak Bharat menuju Kota Subulussalam kita akan di suguhkan oleh pemandangan yang sangat pempesona karena hamparan perbukitan yang hijau dan juga rimbunnya hutan yang akan menambah pesona alam. Walaupun tergolong kedalam kawasan perbukitan dan memiliki banyak hutan belantara, Kota Subulussalam memiliki iklim yang hangat layaknya daerah pesisir. Iklim yang hangat ini berjalan sepanjang hari bahkan malam. Akan tetapi kota subulussalam memiliki curah hujan yang cukup tinggi sehingga hutan yang terdapat di Kota Subulussalam ini cukup banyak. Hutan yang rimbun menjadi pemasok utama air bersih di kawasan kota madya ini.

Persebararan penduduk Kota Subulussalam belum merata pada tiap kecamatan, dalam hal ini memberikan arti bahwa terdapat kecamatan dengan komposisi penduduk yang lebih besar, namun wilayah kecamatannya lebih kecil dan juga sebaliknya. Penduduk yang mendiami wilayah kota subulussalam sebagian besar terdiri dari etnik boang, pak-pak, jawa, batak, singkil, aceh dan lainya.

Terdapat kelompok etnik yang memiliki jumlah yang lebih banyak yaitu Pakpak, boang, jawa dan singkil. Keempat kelompok etnik tersebut menyebar hamper ke seluruh kecamatan antara lain : Kecamatan Sultan Daulat, Kecamatan Runding, dan 
Kecamatan Simpang Kiri. Sedangkan kelompok etnik batak lebih dominan di Kecamatan Penanggalan.

Penyebaran kelompok jawa merupakan hasil dari program transmigrasi yang dilaksanakan oleh pemerintah pusat yang bertujuan sebagai pemerataan penduduk. Kota Subulussalam terkusus etnik jawa telah tersebar atau membaur. Tidak ada lagi pembatasan atau perbedaan dalam memperoleh akses tertentu. Pada awal kedatangan etnik jawa sering terjadi pengkotak-kotakan antara suku boang dan jawa.

Hal ini tentu menimbulkan konflik di Subulussalam dulunya. Tetapi pada saat ini etnik jawa sudah dapat mengekspresikan budayanya dengan bebas hal ini dapat dilihat dari rangkaian adat istiadat dan pertunjukan kesenian seperti pertunjukan kudalumping. Yang dianggap sebagai ikon seni budaya jawa. Jika dilihat dari persebaran penduduk di Kota Subulussalam pada tahun 2015 masih terpusat di kecamatan simpang kiri. Hal terjadi karena perkembangan ekonomi di wilayah ini jauh lebih pesat dibandingkan kecamatan-kecamatan lain. Banyak penduduk yang di luar kecamatan simpang kiri menggantungkan perekonomiannya di sini.

Masyarakat yang berprofesi sebagai petani juga memanfaatkan bukit-bukit tersebut sebagai tempat atau lahan penanaman sawit dan juga karet. Kota Subulussalam merupakan pusat segala aktivitas masyarakat, sekolah-sekolah SD, SMP, SMA/ MAN baik negeri atau swasta banyak terdapat disana. Awal mekarnya kota Subulussalam pembangunan sarana transportasi, sekolah, ekonomi, dan teknologi gencar dilakukan. Anak sekolah dari berbagai desa atau daerah bersekolah di Kota Subulussalam.

Pada tahun 2011 setiap kecamatan di Subulussalam di berikan bus sekolah guna mengangkut anak sekolah ke Subulussalam. Mengenai dana yang masuk ataupun uang keluar yang terdapat di Subulussalam juga memberikan kemajuan terbukti dengan semakin banyaknya Bank milik swasta maupun Bank daerah. Masyarakat banyak yang menggunakan jasa Bank baik untuk menabung atau meminjam uang untuk pemodalan usaha. Karena perbankan terkusus Bank Daerah memfasilitasi pemodalan. Hal yang paling menarik di kota subulussalam adalah angkutan umumnya yang berplat hitam 
dan bentuknya yang sangat khas berupa mobil pick up dimana pada bagian kiri dan kanan nya diletakkan kursi.

Pada tahun 2015, orang bekerja di sektor perdagangan mencapai 3.488 jiwa atau 8,39 \% dari total penduduk usia kerja. Profesi pada sektor jasa meliputi jasa perusahaan, jasa perorangan, pegawai negeri, TNI/ POLRI. Pada sektor perdagangan, yang mendominasi di pegang oleh suku pak-pak. Hal ini dapat dilihat oleh penulis dari nama-nama toko mereka yang menggunakan marga, seperti bako, berutu, padang, angkat, bintang dan sebaginya. Kemudian barang yang didagangkan merupakan alatalat bangunan, elektronik, pakaian dan sebagainya.

Subulussalam terdiri dari 2 pola pemukiman penduduk yaitu sepanjang aliran sungai serta daerah dataran tinggi. Masyarakat awal merupakan pak-pak boang umumnya tinggal di sepanjang aliran sungai soraya runding. Akan tetapi semenjak tahun 1960-an di bawah pimpinan gubernur ali hasyim disosialisasikan sebuah program pemerintah daerah yang dikenal dengan sebutan resettlement desa ( program pemerintah daerah Nangro Aceh Darusalam untuk memberikan tempat menetap yang baru bagi masyarakat desa yang tertinggal. Pemberlakuan program ini disebabkan oleh beberapa faktor yaitu rendahnya tingkat kesejakteraan orang boang yang lebih menggantungkan hidupnya dari hasil sungai dan juga membebaskan mereka dari bencana musiman “ Banjir”. Berbeda lagi dengan sebagian orang pak-pak yang tinggal di daerah perbukitan, seperti daerah penanggalan. Terdapat pemukiman yang terdiri dari masyarakat tranmigrasi jawa, pak-pak dan batak toba. Kehidupan mereka saat ini lebih baik daripada penduduk yang tinggal di daerah pinggiran sungai. Mereka lebih jauh berkembang dan lebih modern. Jika dilihat dari banyaknya jumlah mesjid di Kota Subulussalam, peneliti dapat menyimpulkan bahwa masyarakat mayoritas menganut agama islam. Hal ini terlihat dalam kehidupan masyarakatnya yang tidak terlepas dari nilai-nilai keislaman. Selain itu, pengaruh islam yang begitu kental dapat dilihat dari pakaian yang dipakai oleh kaum perempuan yang mayoritas menggunakan jilbab.

Pada tanggal 17 agustus 2014 pemerintah memberikan apresiasi terhadap petani yaitu memberikan penghargaan kepada petani berprestasi. Kegiatan ini 
diadakan guna memotivasi untuk para pelaku utama dalam setiap provinsi untuk meningkatkan produktivitas dalam mengelola usaha tani guna pembangunan pertanian. Pemberian penghargaan ini dilakukan berdasarkan proses seleksi yang ketat dan panjang. Mulai dari tingkat kecamatan, kabupaten/kota, provinsi hingga sampai ke tingkat nasional. Berdasarkan seleksi, terpilih 33 provinsi di seluruh Indonesia. Seleksi yang dilakukan di Provinsi Aceh juga berdasarkan proses ketat dan panjang dan kota yang terpilih menjadi kota terbaik dan memenuhi syarat adalah kota Subulussalam.

\section{PENUTUP}

Sejarah Kota Subulussaam, dari awal hingga sampai saat ini adalah sejarah yang begitu panjang, dimulai pada saat Subulussalam merupakan hutan belantara yang memiliki penduduk yang jarang. Awalnya penduduk yang pertama sekali mendiami Subulussalam yaitu Suku pak-pak yang di bentuk saat adanya pemukiman, bertambahnya penduduk melalui program transmigrasi hingga berkembang seperti saat ini menjadi Kota Subulussalam. Nama kota subulussalam diberikan oleh gubernur Aceh yang bernama Prof.Ali Hasymi yang berasal dari salah satu kata dari sebuah ayat Al-qur'an yaitu surah Al-maidah ayat 16 yang berarti “jalan menuju keselamatan”.

Kota Subulussalam merupakan suatu daerah yang sangat strategis, ibukota terletak di empat simpang menuju ke empat kecamatan lain yaitu berada dikecamatan Simpang Kiri dan menuju kecamatan longkip, kecamatan Sultan Daulat, kecamatan runding. Kota ini merupakan daerah hasil pemekaran dari kabupaten Aceh Singkil yang baru 9 tahun, tepatnya tanggal 2 januari 2007.

Kota Subulussalam terbentuk dengan keluarnya undang-undang RI Nomor 8 tahun 2007. Pada saat pembentukan pada tahun 2007, Kota Subulussalam terdiri dari 5 (lima) Kecamatan dengan 74 kampung/desa yaitu Kecamatan Simpang Kiri (14 desa), Kecamatan Penanggalan (10 desa), Kecamatan Rundeng (23 desa), Kecamatan Sultan Daulat (17 desa) serta Kecamatan Longkib (10 desa). Transportasi membuat Kota Subulussalam mengalami perkembangan yang begitu pesat. 
Kota Subulussalam memiliki daerah yang sangat luas, daerahnya mencapai 131,100 hektar. Hal ini memungkinkan tersedianya lahan pertanian dan perkebunan sehingga hasil yang di peroleh dari lahan tersebut merupakan hasil pertanian yang di jadikan sebagai andalan dan merupakan mata pencaharian penduduk Kota Subulussalam. Tanaman yang ditanam seperti karet, sawit dan sayur mayur. Penduduk di kota subulussalam ini sebagian besar merupakan petani. Mereka mengandalkan hasil pertanian sebagai mata pencaharian. Hasil pertanian merupakan hal yang utama dalam meningkatkan perekonomian Kota Subulussalam yang sebagian besar terdiri dari Kecamatan Runding, Kecamatan Sultan Daulat, Kecamatan Penanggalan, Kecamatan Simpang Kiri dan Kecamatan Longkip.

Fasilitas-fasilitas yang ada di Kota Subulussalam berdatangan untuk mencari pekerjaan, memanfaatkan sarana transportasi. Hal ini membuat kota Subulussalam terus tumbuh dan berkembang seiring berkembangnya zaman. Pertumbuhan penduduk yang cukup tinggi membuat kota Subulussalam semakin padat, berbagai etnis berkumpul menjadi satu mulai dari suku Pak-pak, jawa, Aceh, minang dan lainnya.

\section{DAFTAR REFERENSI}

Badan Pusat Statistik (2014). Kota Subulussalam. Kota Subulussalam dalam Angka 2014.

Basundoro, Purnawan (2012).Pengantar Sejarah Kota.Ombak:Yogyakarta

Bintarto, R (1983).Interaksi desa-kota dan Permasalahannya.Ghalia Indonesia:Jakarta

Daldjoeni, N, (1998).Geografi Kota dan Desa. Penerbit Alumni:Bandung Menno S, Alwi Mustamin, (1992). Antropologi Perkotaan.CV Rajawali: Jakarta Yunus, S. Hadi, (2009).Klasifikasi Kota.Pustaka Pelajar:Yogyakarta Mirsa, Rinaldi, (2012).Elemen Tata Ruang Kota.Graha Ilmu:Yogyakarta Sugiharto, (2008 ).Pembangunan Dan Pengembangan Wilayah.USU Press:Medan Kartodidjo,sartono, (1977).Masyarakat Kuno dan Kelompok-Kelompok Sosial.bhratara karya aksara: Jakarta Sugiyono (2013).Metode Penelitian Pendidikan.Alfabeta:Bandung Sjamsudddin,helius (2012).Metodologi Sejarah,Ombak:Yogyakarta Tanjung,flores,dkk.(2010). Dairi Dalam Kilatan Sejarah.Perdana Publishing: Medan Sahmudin.(2010).Kelompok Etnik Boang Di Subulussalam Provinsi Nangroe Aceh Darussalam.Tesis.Universitas Negeri Medan. 